\title{
Molecular characterization of ancient algal mats from the McMurdo Dry Valleys, Antarctica
}

\author{
DOUG E. ANTIBUS ${ }^{1,4}$, LAURA G. LEFF ${ }^{1}$, BRENDA L. HALL ${ }^{2}$, JENNY L. BAESEMAN ${ }^{3}$ and \\ CHRISTOPHER B. BLACKWOOD ${ }^{1}$ \\ ${ }^{I}$ Department of Biological Sciences, 256 Cunningham Hall, Kent State University, Kent, OH 44242, USA \\ ${ }^{2}$ Department of Earth Sciences, 5790 Bryand Global Sciences Center, Orono, ME 04469-5790, USA \\ ${ }^{3}$ International Arctic Research Center, University of Alaska Fairbanks, PO Box 757340, Fairbanks, AK 99775-7340, USA \\ ${ }^{4}$ Room 3316, National Center for Agricultural Utilization Research, 1815 N. University Street, Peoria, IL 61604, USA \\ dantibus@gmail.com
}

\begin{abstract}
The McMurdo Dry Valleys possess a cold and dry climate which favours biomolecular preservation, and present the possibility for preservation of biological materials over long timescales. We examined patterns of bacterial DNA abundance and diversity in algal mats from 8-26539 years of age. Bacterial DNA abundance was inferred from extractable DNA quantity and quantitative polymerase chain reaction targeting the bacterial 16S rRNA gene. Because damage to bacterial DNA could limit its availability for polymerase chain reaction, the efficacy of DNA repair by a commercially available kit was also examined. Polymerase chain reaction amplicons of the bacterial 16S rRNA gene were obtained from seven of eight samples. Bulk DNA abundance and bacterial 16S rRNA gene copy number of template DNA declined with increasing sample age consistent with expectations of accumulation of DNA damage in ancient materials. Clone libraries revealed age related patterns of abundance for some bacterial phylogenetic groups. For example, Firmicutes and several other lineages were abundant in ancient samples, but Cyanobacteria were absent. This points to a biased persistence of bacterial lineages that change over time since photosynthesis was active.
\end{abstract}

Received 26 October 2010, accepted 9 August 2011, first published online 15 November 2011

Key words: ancient bacterial DNA, microbial dormancy, Victoria Land, 16S rRNA

\section{Introduction}

Terrestrial Antarctic habitats are challenging for microbial growth and survival due to low temperatures, freeze-thaw cycles, and scarcity of liquid water. These unfavourable conditions result in short growing seasons, and microorganisms are forced to undergo periodic dormancy. Friedmann et al. (1993) estimated that cryptoendolithic communities in the McMurdo Dry Valleys are metabolically active for only $400-1000$ hours per year. Despite these conditions, a diverse microbial flora exists in the Antarctic, including the Dry Valleys, suggesting that Antarctic microbes possess adaptations that confer tolerance to environmental stresses (reviewed in Vincent 2000). Although the manner in which Antarctic biota are adapted to low temperatures has received a large amount of scientific attention, adaptations to tolerate desiccationrehydration and freeze-thaw cycles have received less attention (e.g. Davey 1989, Šabacká \& Elster 2006).

Algal mat communities (including eukaryotic algae, heterotrophic and autotrophic bacteria, and archaea) are a common microbial growth form in the Dry Valleys and are important contributors to primary productivity and biogeochemical cycles (Ellis-Evans 1996). Research on the response of these mats to desiccation has primarily examined effects on photosynthetic community members over annual or decadal timescales. Hawes et al. (1992) observed viable cyanobacteria in mats several years of age, and McKnight et al. (2007) observed microbial growth, carbon fixation, and nitrogen fixation upon rehydration of stream algal mat communities which had been desiccated for more than two decades. However, the potential for microbes and microbial DNA to persist over millennialscale periods of desiccation-imposed dormancy in the Dry Valleys has not been investigated.

Deposits of algal mats dating to the late Holocene are found in the Dry Valleys as remnants of glacial lakes (Hall et al. 2001, 2002). These mats, in addition to other palaeosediment deposits, have been identified as "legacy" carbon sources to the Dry Valley ecosystems (Moorhead et al. 1999).

The cold desert climate of the Dry Valleys (Doran et al. 2002) is expected to favour preservation of biomolecules. Polymerase chain reaction (PCR)-amplifiable DNA has been recovered from Adélie penguin bones $>5000$ years of age in the Dry Valleys region (Ritchie et al. 2004). The persistence of viable bacterial cells and DNA in glacial ice and permafrost has been extensively studied. Viable cells and DNA have been recovered from ice and permafrost that formed several hundred thousand years ago (e.g. Christner et al. 2003, Johnson et al. 2007). In contrast, preservation of bacterial cells and DNA over long-term desiccation has 
Table I. Sample ${ }^{14} \mathrm{C}$ ages (years BP) and locations of origin. The age of the modern sample (8) is based on the date of collection.

\begin{tabular}{llc}
\hline${ }^{14} \mathrm{C}$ Age & Location & Age class \\
\hline 8 & Victoria & 1 \\
8619 & Wright & 2 \\
8643 & Victoria & 2 \\
11164 & Victoria & 3 \\
11851 & Victoria & 3 \\
12303 & Victoria & 3 \\
12910 & Taylor & 3 \\
26539 & Wright & 4 \\
\hline
\end{tabular}

not been extensively studied, due, in part, to a lack of suitable environments (Billi \& Potts 2002).

Because of the lack of information on the potential for persistence of microbial DNA in ancient materials in the Dry Valleys, the occurrence of bacterial DNA in samples of algal mats representing a chronological sequence from 8-26539 years of age was examined in this study. Mat samples originated from Taylor, Wright, and Victoria valleys. Sample ages, determined by radiocarbon $\left({ }^{14} \mathrm{C}\right)$ dating, are thought to represent the last time moisture levels supported significant primary production and heterotrophic activity (Hall et al. 2001, 2002). If DNA was preserved in these ancient mat samples, we expected the quantity of extractable DNA, the quantity of PCR-amplifiable bacterial 16S rRNA templates (scaled to total DNA), and the richness of bacterial 16S rRNA templates to decline with increasing sample age due to accumulation of damage in DNA molecules (Willerslev \& Cooper 2005). This study had three primary purposes: 1 ) to establish whether algal mat samples displayed patterns of DNA preservation consistent with expectations for ancient materials, 2) to explain differences in microbial assemblages (as revealed by 16S rRNA gene sequences) based on sample age and geographical location, and 3) to evaluate the use of DNA repair as a means for recovering a greater diversity of gene sequences from ancient samples.

\section{Materials and methods}

\section{Sample collection and characterization}

Algal mat samples used in this study were collected from Victoria, Wright, and Taylor valleys (Table I). Individual samples are referred to by their ${ }^{14} \mathrm{C}$ age in years BP (e.g. the sample dating to 12910 years BP is referred to as 12910). Samples were collected from $5-15 \mathrm{~cm}$ below the soil surface. Sample 8619 was previously described in Hall et al. (2001), samples 8643, 11185, and 12303 were described in Hall et al. (2002), and sample 12910 was described in Hall \& Denton (2000). Samples 11164 and 26539 have not previously been described in publications, but sample collection and method of age determination were identical to those for other samples. Samples were collected aseptically and stored dried at room
Table II. DNA yield ( $\mathrm{ng} \mathrm{mg}^{-1}$ ) of samples during successive rounds of extraction. Error values are the standard error of triplicate

measurements. ND denotes DNA quantity was below limits of detection.

\begin{tabular}{llccl}
\hline Sample & First round & Second round & Third round & Total \\
\hline 8 & $1.75 \pm 0.16$ & $0.334 \pm 0.095$ & - & 2.09 \\
8619 & $0.95 \pm 0.034$ & $0.026 \pm 0.036$ & - & 0.979 \\
8643 & $1.34 \pm 0.16$ & $0.156 \pm 0.082$ & - & 1.49 \\
11164 & $0.067 \pm 0.011$ & $0.055 \pm 0.039$ & - & 0.123 \\
11185 & $0.071 \pm 0.018$ & ND & - & 0.071 \\
12303 & $0.026 \pm 0.009$ & ND & - & 0.026 \\
12910 & $0.186 \pm 0.004$ & $0.194 \pm 0.024$ & $0.036 \pm 0.008$ & 0.414 \\
26539 & $0.029 \pm 0.006$ & ND & - & 0.029 \\
\hline
\end{tabular}

temperature until analysis. Sample 8 was collected from Upper Victoria Lake in 2001 and the age of this sample is based on the collection date rather than ${ }^{14} \mathrm{C}$ age.

\section{DNA extraction}

DNA was extracted using Epicentre SoilMaster DNA kits (Epicentre Biotechnologies, Madison WI), following the manufacturer's directions with modifications. The extraction procedure included bead-beating, repetition of extractions with fresh buffer, and incubation at $65^{\circ} \mathrm{C}$ to facilitate extraction of DNA from recalcitrant cells, such as endospores. DNA was extracted from 100-150 mg of material for ancient samples and $40 \mathrm{mg}$ of material for sample 8 . Extracted DNA was dissolved in $10 \mathrm{mM}$ Tris $(\mathrm{pH} 8.0)$ and stored at $-20^{\circ} \mathrm{C}$. DNA was divided into aliquots for quantitation, PCR amplification, and enzymatic repair and quantitative PCR (Q-PCR). A second round of extraction was performed on all samples to assess efficiency of DNA recovery during the first round of extraction (Feinstein et al. 2009). To accomplish this, the microbial mat pellet remaining after cell lysis was stored at $-20^{\circ} \mathrm{C}$ and subjected to a second round of extraction by the same procedure. One sample (sample 12910) was also subjected to a third round of extraction because the amount of DNA recovered was comparable in the first and second rounds of extraction (Table II). Only DNA recovered from the first extraction was used for repair, Q-PCR, and cloning. Negative controls consisted of sterile water and were performed alongside extractions at a ratio of one control to four extractions.

Extracted DNA was quantified by the Picogreen dye fluorescence assay (Invitrogen Molecular Probes, Eugene OR). Fluorescence was read at $\lambda_{\mathrm{ex}} 480 \mathrm{~nm}$ and $\lambda_{\mathrm{em}} 520 \mathrm{~nm}$ in a Synergy 2 plate reader (Biotek Instruments, Winooski VT). DNA concentration was calculated by comparison to a standard curve of bacteriophage $\lambda$ DNA diluted to $0.05-5.0 \mathrm{ng} \mu \mathrm{l}^{-1}$.

\section{DNA repair}

Bulk DNA extracts were repaired using the PreCR DNA repair kit (New England Biolabs, Ipswich MA). Repair reactions $(20 \mu \mathrm{l})$ contained the following: 1X NEB 
Thermopol buffer $\left(10 \mathrm{mM} \mathrm{KCl}, 10 \mathrm{mM}\left(\mathrm{NH}_{4}\right)_{2} \mathrm{SO}_{4}, 20 \mathrm{mM}\right.$ Tris-HCl, $2 \mathrm{mM} \mathrm{MgSO}_{4}, 0.1 \%$ Triton $\mathrm{X}-100, \mathrm{pH} 8.8$ ), $1 \mu \mathrm{g}^{-1}$ BSA, $0.1 \mathrm{mM}$ each dNTP, $0.5 \mathrm{mM} \mathrm{NAD}^{+}$, and $1 \mathrm{X}$ repair enzyme mixture. Reactions were incubated for $120 \mathrm{~min}$ at room temperature $\left(\right.$ c. $\left.22^{\circ} \mathrm{C}\right)$ and stored at $-20^{\circ} \mathrm{C}$ until analysis. Repair negative controls (RNCs) consisted of the repair master mix including enzyme mixture plus $5 \mu l$ of sterile water in place of template. Unrepaired negative controls (UNCs) were also performed and consisted of repair master mix without enzymes plus $5 \mu$ l of sterile water. Repair negative controls and UNCs were performed in duplicate. To control for the effect of repair buffer on Q-PCR reactions, unrepaired template was diluted with repair buffer lacking enzymes to $1 \mathrm{X}$ concentration prior to amplification.

\section{$Q-P C R$}

Quantitative polymerase chain reaction was performed using the primers Eub338F-0-III (Blackwood et al. 2005) and 518R (Fierer et al. 2005). A Q-PCR standard was constructed by diluting plasmid containing a bacterial ribosomal gene insert, in a tenfold dilution series from $2.5 \times 10^{7}-2.5 \times 10^{2}$ copies $\mu l^{-1}$. Plasmid was diluted in repair mastermix lacking enzymes. Polymerase chain reaction reagent concentrations in a reaction volume of $25 \mu \mathrm{l}$ were as follows: $0.16 \mu \mathrm{M}$ each primer, $0.2 \mathrm{mM}$ each

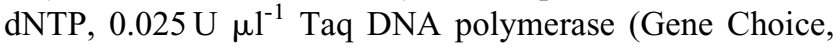
Frederick MD), 1x ammonium buffer $(1.5 \mathrm{mM} \mathrm{MgCl}$, $75 \mathrm{mM}$ Tris- $\mathrm{HCl}, 20 \mathrm{mM}\left(\mathrm{NH}_{4}\right)_{2} \mathrm{SO}_{4}, 0.1 \%$ Tween 20 , pH 8.5), $0.5 \mathrm{mM} \mathrm{MgCl}_{2}$ (total $2.0 \mathrm{mM} \mathrm{MgCl}{ }_{2}$ ), $0.1 \mu \mathrm{g} \mu \mathrm{l}^{-1}$ BSA, 0.5-2.0 $\mu$ l template DNA, 0.167X Sybr Green, and $30 \mathrm{nM}$ 5-ROX. Cycling conditions were as follows: an initial denaturation step of $3 \mathrm{~min}$ at $95^{\circ} \mathrm{C}$, followed by 45 cycles of $30 \mathrm{sec}$ at $95^{\circ} \mathrm{C}, 30 \mathrm{sec}$ at $57^{\circ} \mathrm{C}$, and $90 \mathrm{sec}$ at $72^{\circ} \mathrm{C}$, and a final elongation step of $7 \mathrm{~min}$ at $72^{\circ} \mathrm{C}$. Amplification was performed in a Stratagene MX3005P thermal cycler (Agilent Technologies, Santa Clara CA). Triplicate notemplate controls (NTCs), in which water was used in place of template, were also performed. Sample copy number was calculated by comparing sample $C_{t}$ to the curve calculated from standard $C_{t}$ values. Starting template copy number of repair reactions was compared directly to that of unrepaired template DNA diluted to an identical level $(1: 5,1: 20$, or 1:80) in repair buffer lacking enzymes. Template copy number of RNCs and UNCs were also assayed. Calculated sample copy number was standardized per ng of template DNA.

\section{Statistical analyses of DNA yield and Q-PCR data}

The relationship between DNA yield and age was tested with a Pearson product-moment correlation of yield $\left(\log _{10}\right.$ transformed prior to analysis) and sample age (expressed in years BP). Sample ages were divided into four age classes (Table I) for some statistical analyses. Quantitative polymerase chain reaction data were analysed with a linear mixed model, with age (expressed as one of four age classes) designated a covariate, repair designated a fixed effect, and sample designated a random effect (with one repaired and one unrepaired value per sample). Quantitative polymerase chain reaction data were expressed as 16S rRNA copies per ng DNA and was $\log _{10}$ transformed prior to analysis. Statistical analyses were performed in R (version 2.9.1).

\section{Amplification and cloning of environmental $16 S$ rRNA genes}

Bacterial 16S rRNA genes were amplified by PCR using the primers Eub338F-0-III (Blackwood et al. 2005) and 1391R (Barns et al. 1994). Reagent concentrations were identical to those for Q-PCR except that SybrGreen and ROX were not used. Cycling was also identical to Q-PCR except that 35 cycles were used rather than 45 , and cycling was carried out in a DNA Engine Dyad Cycler (BioRad, Hercules CA). All PCR reactions were carried out in triplicate. Duplicate NTCs, in which template was substituted with water, were included in each set of reactions.

Triplicate PCR products were pooled and treated with a MoBio Ultra-Clean PCR purification kit (MoBio Laboratories, Carlsbad CA) and PCR products were cloned into E. coli using the TOPO TA cloning kit (Invitrogen, Carlsbad CA) according to manufacturer's directions. Libraries of 96 clones were picked from each cloning reaction. Clone libraries of PCR products from unrepaired template DNA were obtained from all samples except 12303. Clone libraries of PCR products from repaired template DNA were obtained from samples 8, 8619, and 26539. Clone inserts were sequenced by the Genome Sequencing Center at Washington University of Saint Louis. Sequencing reads were obtained from both ends of inserts using primers T7F (5'- TAA TAC GAC TCA CTA TAG GG) and M13R (5'- CAG GAA ACA GCT ATG AC).

\section{Sequence data analysis}

Non-chimeric sequences containing the $338 \mathrm{~F}$ primer site were used for statistical data analysis (a total of 750 sequences). Sequence alignment and chimeric sequence detection were performed by the NAST (Nearest Alignment Space Termination) alignment tool and Bellerophon version 3.0 respectively, from the GreenGenes workbench (http:// greengenes.lbl.gov, accessed May 2009). A total of 26 chimeric sequences were removed from the dataset. In addition, 335 contig sequences were formed by combining reads from 338F and 1391R ends. Sequences were deposited in GenBank with accession numbers HM356029-HM357113. The Ribosomal Database Project (RDP) classifier tool (Wang et al. 2007) was used to classify clone sequences to phylum. Sequences classified with less than $80 \%$ confidence were considered 'unclassified'. In order to better understand the phylogenetic affiliation of contig sequences, BLAST searches were performed to identify close relatives of these sequences 


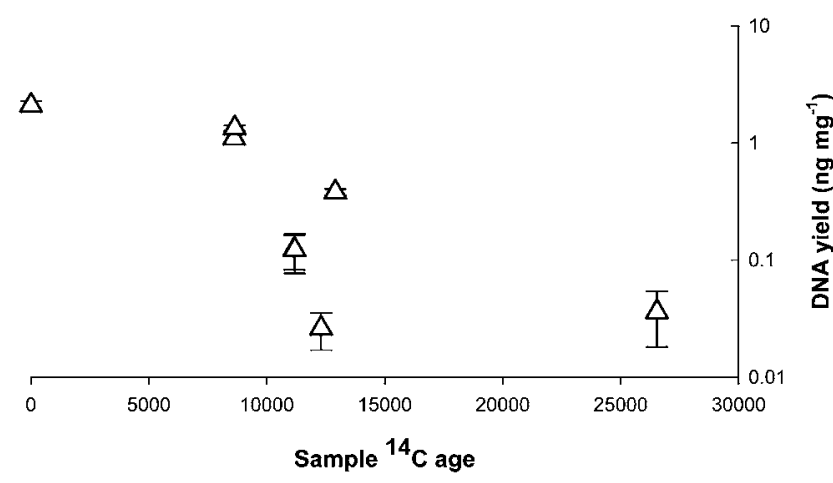

Fig. 1. Bulk DNA yield (ng DNA per mg of sample) of algal mat samples. Sample ${ }^{14} \mathrm{C}$ age is expressed in years BP. Error bars represent the standard error of triplicate DNA quantitation experiments.

in GenBank (http://blast.ncbi.nlm.nih.gov/Blast.cgi, accessed May 2009). For classification into operational taxonomic units (OTUs), matrices of pairwise Jukes-Cantor corrected distances were calculated in MEGA (version 4.0). Groups of OTUs were identified in DOTUR (Schloss \& Handelsman 2005) using a 3.0\% distance cut-off. Rarefaction curves and richness/ diversity statistics were calculated in Estimate S (version 8.2, http://purl.oclc.org/estimates). Distance-based redundancy analysis (RDA) (Legendre \& Anderson 1999) was used to test for effects of sample age, the valley from which samples originated, and DNA repair. For RDA, the distance matrix among samples was subjected to principal co-ordinates analysis $(\mathrm{PCOA})$ and the resulting $\mathrm{PCoA}$ matrix was corrected for negative eigenvalues by adding a constant before RDA was performed (Legendre \& Anderson 1999). Steps of RDA were performed in CANOCO (version 4.5) (Microcomputer Power, Ithaca NY) using a Monte-Carlo test of significance with 999 permutations. Separate RDA analyses were performed using each of two distance metrics: a) the Hellinger distance of square root transformed relative OTU abundances, and b) the Unifrac distance among samples incorporating the phylogenetic distance between sequences (Lozupone et al. 2006). The lineage analysis available in Unifrac was also used to investigate the distribution of sequence groups with respect to sample age. This analysis performs a G-test based on the abundance of sequences among "environments" and tests the null hypothesis that sequence groups are distributed evenly among environments (Lozupone et al. 2006).

\section{Results}

Bulk DNA abundance and 16S rRNA gene content

Bulk extractable DNA was measured to assess differences in DNA content between samples. All samples were subjected to two rounds of DNA extraction and one sample (sample 12910) was subjected to a third round of

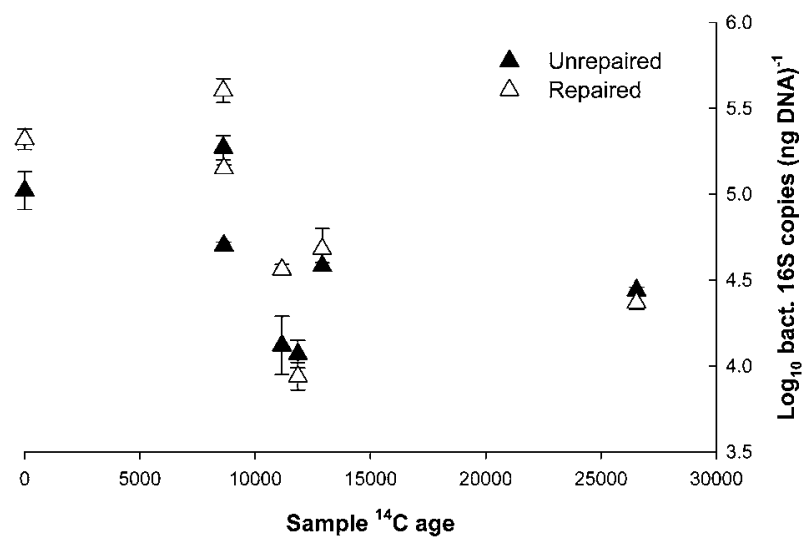

Fig. 2. Quantitative polymerase chain reaction (Q-PCR) quantitation of the bacterial $16 \mathrm{~S}$ rRNA gene in repaired and unrepaired template DNA. Error bars represent standard errors from at least triplicate Q-PCR experiments.

extraction because DNA recovery did not decrease between the first and second extractions. DNA yields from the first round of extraction represented, on average, $75 \%$ of total DNA yield (Table II). Total DNA yield was negatively correlated with sample age $(P<0.001$, Fig. 1$)$.

Bacterial 16S rRNA gene abundance was measured by Q-PCR to assess differences in bacterial DNA integrity among samples (Fig. 2). To test for inhibition of the Q-PCR reaction by DNA extracts, positive controls were "spiked" with standard DNA (described above) at various concentrations. Spiked controls did not show evidence of PCR inhibition relative to unspiked controls (data not shown). Bacterial 16S rRNA genes were detected in all samples except

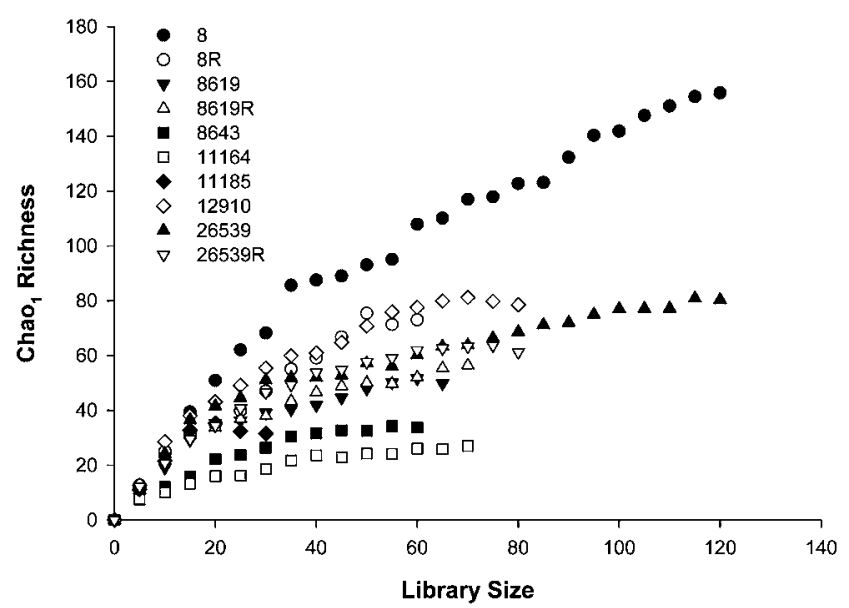

Fig. 3. Rarefaction analysis of bacterial 16S rRNA gene clone libraries. Rarefaction curves of Chao's richness estimator $\left(\mathrm{Chao}_{1}\right)$ were constructed in Estimate S (http://purl.oclc.org/ estimates). Sample ages followed by " $R$ " indicate libraries from repaired template DNA. 


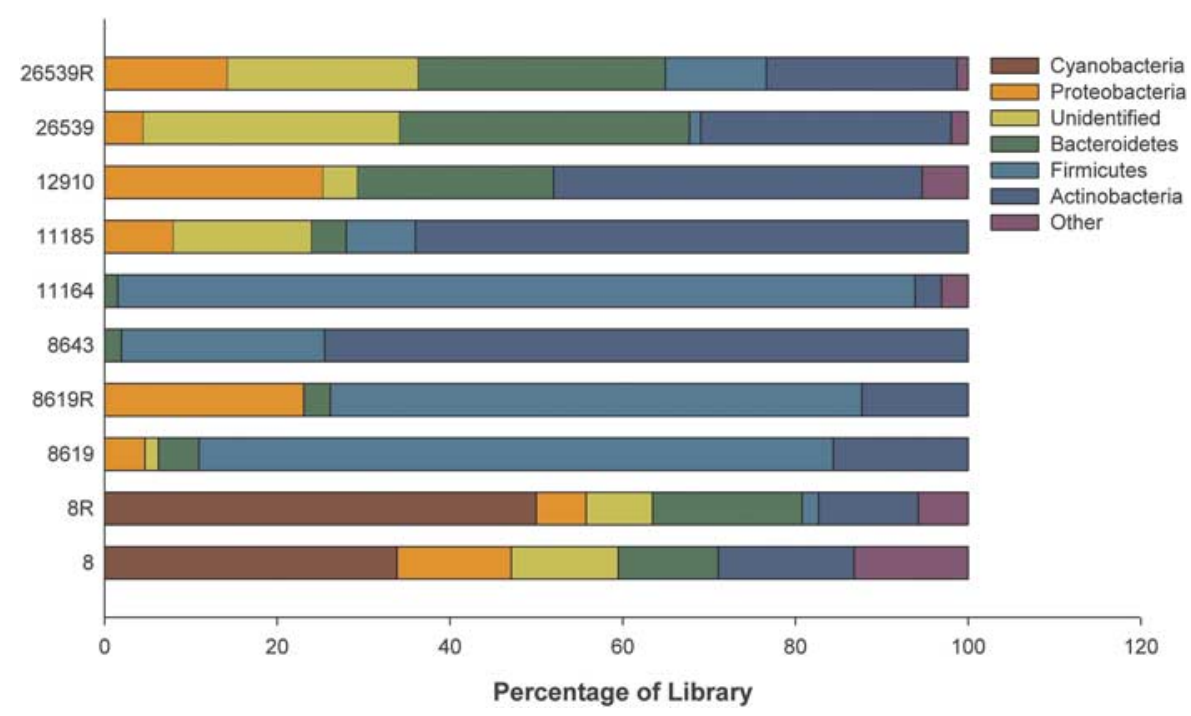

Fig. 4. Proportional abundance of dominant phyla in bacterial $16 \mathrm{~S}$ rRNA gene clone libraries. Sample ages followed by " $R$ " indicate libraries from repaired template DNA. sample 12303. Sample age had a significant effect on target gene copy number, scaled to total DNA ( $P<0.05$, Fig. 2$)$. This effect remained significant when the oldest sample (26539) was excluded from the analysis. Repair of template DNA was attempted to allow PCR amplification of damaged DNA molecules. Repair treatment had a marginally significant effect on 16S rRNA gene copy number of templates $(P=0.057)$. Gene copy number of repaired templates was on average 1.9-fold higher than that of unrepaired templates. The interaction between sample age and repair was nonsignificant $(P=0.15)$.

\section{Bacterial diversity and community composition}

To examine the effects of sample age on bacterial community composition, clone libraries of the bacterial 16S rRNA gene were constructed from all samples except 12303 (which did not yield 16S rRNA gene PCR products). Additional clone libraries were constructed using repaired template DNA from samples 8,8619 , and 26539. These libraries are referred to as 8R, 8619R and 26539R. Polymerase chain reactions using extraction negative controls as templates did not yield products.

Table III. Phylogenetic affiliation of groups unevenly distributed among sample age classes according to Unifrac lineage-specific analysis $(P<0.05)$. Sequences from nearest cultured relatives were retrieved by BLAST. Multiple entries for a phylum represent separate operational taxonomic units within that phylum.

\begin{tabular}{|c|c|c|c|c|}
\hline Phylum & Age class & Nearest relative & $\%$ Max. identity & GenBank accession \\
\hline Firmicutes & 2,3 & Sporosarcina macmurdoensis & 99 & AJ514408 \\
\hline Bacteroidetes & 3,4 & Adhaeribacter aquaticus & 96 & AJ626894 \\
\hline Bacteroidetes & 3,4 & Roseivirga spongicola & 91 & DQ080996 \\
\hline Bacteroidetes & 3,4 & Gillisia sp. & 97 & FJ889660 \\
\hline Chloroflexi & 1 & none $>90 \%$ & - & - \\
\hline Firmicutes & 2,3 & Desulfosporosinus lacus & 98 & AJ582757 \\
\hline Firmicutes & 2,3 & Clostridium tagluense & 99 & DQ296031 \\
\hline Firmicutes & 2,3 & Psychrosinus fermentans & 99 & DQ767881 \\
\hline Firmicutes & 2,3 & none $>90 \%$ & - & - \\
\hline Firmicutes & 2,3 & none $>90 \%$ & - & - \\
\hline Firmicutes & 2,3 & Desulfotomaculum sp. & 92 & AJ577273 \\
\hline Gemmatimonadetes & 4 & none $>90 \%$ & - & - \\
\hline Chloroflexi & 4 & Sphaerobacter thermophilus & 90 & AJ420142 \\
\hline
\end{tabular}


A total of 750 non-chimeric sequences were acquired, which were classified into 215 OTUs using a Jukes-Cantor corrected distance of 3.0\% (Stackebrandt \& Goebel 1994). Rarefaction curves of Chao's richness estimator $\left(\mathrm{Chao}_{1}\right)$ approached an asymptote for all libraries, with the exception of the library from unrepaired template from sample 8 (Fig. 3). Richness was not significantly correlated with sample age $(P=0.30)$.

Clone sequences were classified to phylum using the Ribosomal Database Project classifier tool (Wang et al. 2007). Clone libraries were dominated by sequences belonging to the Actinobacteria (25.7\% of all sequences), Firmicutes (23.1\% of all sequences), and Bacteroidetes (16.2\% of all sequences) (Fig. 4). Sequences belonging to Cyanobacteria were abundant in sample 8 but were not recovered from any ancient samples.

Distance-based redundancy analysis was used to test for effects of sample age and valley of origin ("location") on sample community composition. The effect of age was tested by dividing samples into four age classes (Table I). The effects of both location ( $P=0.350,15 \%$ of total variance) and age $(P=0.110,21 \%$ of total variance) were non-significant using both Hellinger distance calculated from OTU abundances and Unifrac distance (Lozupone et al. 2006), although age explained a greater amount of variation than location. The effects of repair on clone library richness $(P=0.55)$ and composition $(P=0.90)$ were non-significant.

\section{Distribution of bacterial taxa across sample age}

Analysis of lineages performed using Unifrac (Lozupone et al. 2006) was used to determine whether phylogenetic groups were unevenly distributed among age classes $(P<0.05$, Table III). Two groups found in sample 8 were not found in any ancient samples: Cyanobacteria, and a group of sequences belonging to the Chloroflexi. Sequence groups belonging to the Firmicutes were overabundant in age classes 2 and 3. Groups belonging to the Actinobacteria and Bacteroidetes were overabundant in age classes 2,3 , and 4 , and a group weakly affiliated with the Chloroflexi (a different group than found in sample 8) and the Gemmatimonadetes were abundant in age class 4 (sample 26539).

\section{Discussion}

DNA was recovered from all of the ancient mat samples and could be amplified with bacterial specific primers from all but one sample. Bulk extractable DNA and bacterial 16S rRNA gene abundance (scaled to total DNA) both declined with increasing sample age. These results match the expectation that the amount of DNA and its integrity will decline with increasing sample age, due to accumulation of damage over time (Willerslev \& Cooper 2005).

In contrast, richness of $16 \mathrm{~S}$ rRNA gene clone libraries, at the level of OTUs, was not affected by sample age. However,
Table IV. Diversity and richness estimates for 16S rRNA gene clone libraries. For $\mathrm{Chao}_{1}$ and $\mathrm{S}_{\mathrm{obs}} 95 \%$ upper and lower confidence limits are given in parentheses.

\begin{tabular}{lcccc}
\hline Sample & Shannon's $H$ & Chao $_{1}$ & $\mathrm{~S}_{\text {obs }}$ & Coverage \\
\hline 8 & $3.01 \pm 0.15$ & $152(104-259)$ & $66(52-80)$ & 0.70 \\
$8 \mathrm{R}$ & $2.84 \pm 0.1$ & $73(45-159)$ & $31(21-41)$ & 0.71 \\
8619 & $2.72 \pm 0.13$ & $49(36-92)$ & $30(21-39)$ & 0.73 \\
$8619 \mathrm{R}$ & $2.83 \pm 0.11$ & $57(40-113)$ & $32(22-42)$ & 0.66 \\
8643 & $2.3 \pm 0.13$ & $33(23-76)$ & $20(12-28)$ & 0.78 \\
11164 & $2.08 \pm 0.15$ & $27(20-58)$ & $18(10-26)$ & 0.89 \\
11185 & $2.78 \pm 0.03$ & $31(23-61)$ & $20(12-28)$ & 0.56 \\
12910 & $3.06 \pm 0.11$ & $79(57-136)$ & $44(32-56)$ & 0.61 \\
26539 & $2.91 \pm 0.14$ & $81(64-125)$ & $54(42-66)$ & 0.85 \\
$26539 \mathrm{R}$ & $2.76 \pm 0.11$ & $61(44-112)$ & $35(26-43)$ & 0.71 \\
\hline
\end{tabular}

richness of ancient samples was generally lower than that of the modern sample: a greater number of phyla ( 11 phyla) were detected from the modern sample than from ancient samples (four to seven phyla), and OTU richness in that sample was significantly higher than four of six ancient samples. Richness estimates for unrepaired template from ancient samples varied from 27-81 OTUs (Table IV). These results are similar to richness estimates from bacterial 16S rRNA gene clone libraries from Dry Valleys soils (Aislabie et al. 2006, 29-85; Smith et al. 2006, 49-57). Although these findings are generally consistent with expectations for ancient samples, we cannot exclude the possibility that there was colonization of these environmental samples by extant microorganisms during the millennia since active photosynthesis and burial.

Clone library composition was not affected by sample age, but several sequence groups were unevenly distributed among sample age classes. Sequences belonging to the Cyanobacteria were only found from sample 8. Because Cyanobacteria are abundant in modern Antarctic algal mat communities, the absence of Cyanobacteria sequences from ancient samples was unexpected. Potential explanations for this observation include the possibility that Cyanobacteria DNA or cells are not well-preserved over long-term dormancy. Cyanobacteria are known to maintain viability (which is dependent on DNA integrity) over year and decade-long periods of desiccation in a variety of habitats including the Dry Valleys (Davey 1989, Hawes et al. 1992, McKnight et al. 2007). Information on the integrity of Cyanobacteria DNA over longer periods of dormancy is lacking (Billi \& Potts 2002). But, Shirkey et al. (2003) found that PCR amplification of several loci was inhibited by covalent DNA damage in dried Nostoc commune Vauch. greater than 60 years old. Yet, comparisons among studies of ancient cell and DNA preservation are complicated by the lack of information on conditions to which materials have been exposed. Although Cyanobacteria have been isolated from Antarctic permafrost (Gilichinsky et al. 2007), permafrost sediments contain pockets of liquid water which can support microbial metabolism (Rivkina et al. 2000), and thus may not be appropriate analogues for Dry Valleys soils where water is scarce. 
An alternative explanation for the lack of Cyanobacteria DNA sequences from ancient samples in this study is that Cyanobacteria DNA/biomass were degraded by heterotrophic bacteria during periods of rewetting. Although ${ }^{14} \mathrm{C}$ values of samples represent an average age for organic molecules in the sample, it is possible that this carbon may have been recycled by heterotrophs.

Sequences belonging to the Firmicutes, Actinobacteria, and Bacteroidetes were found in all samples, but were overabundant in ancient samples. Because heterotrophic community members of Antarctic algal mats have been studied less frequently than phototrophic members, there is a limited amount of information with which to compare our results. Brambilla et al. (2001) found that a bacterial 16S rRNA gene clone library from a Lake Fryxell algal mat was dominated by members of the Firmicutes (41\%), Bacteroidetes (24\%), Proteobacteria (18\%) and Verrucomicrobiales (11\%). Actinobacteria and Bacteroidetes have been found in a variety of habitats within the Dry Valleys, including soils and algal mats, by both cultivation based and molecular methods (Brambilla et al. 2001, Van Trappen et al. 2002, Moodley 2004, Aislabie et al. 2006, Smith et al. 2006). Retrieval of sequences belonging to Actinobacteria and Bacteroidetes was unexpected. Actinobacteria and gram-negative bacteria have been identified in ancient ice and permafrost, but the mechanisms of their persistence in these environments is not clear. Johnson et al. (2007) suggested that DNA of gram-negative and High-GC gram-positive bacteria persists in permafrost due to active DNA repair by cells. Suzina et al. (2004) suggested that formation of cyst-like resting cells allows non-spore-forming bacteria to persist in permafrost. Because we are not able to ensure that the samples have not been rehydrated at some point since their deposition, it is possible that some sequences represent soil bacteria that colonized samples.

Retrieval of sequences belonging to endospore-forming Firmicutes from ancient samples was expected, as Firmicutes endospores are well-known for their persistence under adverse environmental conditions and have been isolated from a variety of materials from hundreds to several thousand years of age (reviewed in Kennedy et al. 1994, Rollo et al. 2007). Firmicutes have not been found to be abundant in Dry Valley mineral soils (Moodley 2004, Aislabie et al. 2006, Smith et al. 2006), but are abundant in other Antarctic habitats, including coastal ornithogenic soils (Aislabie et al. 2008), microbial mats (Brambilla et al. 2001), and sediments (Bowman et al. 2000). Because Firmicutes are abundant in algal mats, but not Dry Valley mineral soils, Firmicutes sequences probably represent bacteria endogenous to the mat samples. Sequences belonging to members of the anaerobic Clostridiales ( $73 \%$ of Firmicutes sequences) were more abundant than sequences belonging to the Bacillales (27\% of Firmicutes sequences). Sequences related to the genus of sulphatereducing bacteria Desulfosporosinus were found in samples 8619 (4.7\% of sequences), 8619R (12.2\% of sequences),
8643 ( $9.8 \%$ of sequences), and 11164 ( $7.6 \%$ of sequences). The abundance of sequences belonging to the Clostridiales and sulphate-reducing bacteria is suggestive of anaerobic conditions and biogeochemical cycling of sulphur, which are typical features of microbial mat communities (Paerl et al. 2000), and provides further evidence that sequences originated from organisms endemic to the mat samples.

\section{Conclusions}

Polymerase chain reaction-amplifiable bacterial DNA abundance and integrity declined with sample age over several millennia. Certain bacterial lineages were unevenly distributed among sample age classes, but community composition did not significantly vary with sample age. By comparison of our data to similar studies of other Antarctic habitats, we infer that differences in taxonomic composition of clone libraries of different ages could be the result of biases in persistence of genetic material or viable cells. The persistence of DNA in these ancient materials points to the possibility for genetic diversity from ancient communities to be transferred to modern communities.

\section{Acknowledgements}

Funding for this research came from Kent State University and from a United States National Science Foundation grant to Dr Jennifer Baeseman (MCB-0729783). The constructive comments of the reviewers are also gratefully acknowledged.

\section{References}

Aislabie, J.M., Jordan, S. \& Barker, G.M. 2008. Relation between soil classification and bacterial diversity in soils of the Ross Sea region, Antarctica. Geoderma, 144, 9-20.

Aislabie, J.M., Chhour, K., Saul, D.J., Miyauchi, S., Ayton, J., Paetzold, R.F. \& BALKs, M.R. 2006. Dominant bacteria in soils of Marble Point and Wright Valley, Victoria Land, Antarctica. Soil Biology and Biochemistry, 38, 3041-3056.

Barns, S.M., Fundyga, R.E., Jeffries, M.W. \& Pace, N.R. 1994. Remarkable archaeal diversity detected in a Yellowstone National Park hot spring environment. Proceedings of the National Academy of Sciences of the United States of America, 91, 1609-1613.

Billi, D. \& Potts, M. 2002. Life and death of dried prokaryotes. Research in Microbiology, 153, 7-12.

Blackwood, C.B., OAKs, A. \& Buyer, J.S. 2005. Phylum- and classspecific PCR primers for general microbial community analysis. Applied and Environmental Microbiology, 71, 6193-6198.

Bowman, J.P., Rea, S.M., McCammon, S.A. \& McMeekin, T.A. 2000. Diversity and community structure within anoxic sediment from marine salinity meromictic lakes and a coastal meromictic marine basin, Vestfold Hills, Eastern Antarctica. Environmental Microbiology, 2, 227-237.

Brambilla, E., Hippe, H., Hagelstein, A., Tindall, B.J. \& Stackebrandt, E. 2001. 16S rDNA diversity of cultured and uncultured prokaryotes of a mat sample from Lake Fryxell, McMurdo Dry Valleys, Antarctica. Extremophiles, 5, 23-33.

Christner, B.C., Mosley-Thompson, E., Thompson, L.G. \& Reeve, J.N. 2003. Bacterial recovery from ancient glacial ice. Environmental Microbiology, 5, 433-436. 
Davey, M.C. 1989. The effects of freezing and desiccation on photosynthesis and survival of terrestrial Antarctic algae and cyanobacteria. Polar Biology, 10, 29-36.

Doran, P.T., McKay, C.P., Clow, G.D., Dana, G.L., Fountain, A.G., Nylen, T. \& Lyons, W.B. 2002. Valley floor climate observations from the McMurdo Dry Valleys, Antarctica, 1986-2000. Journal of Geophysical Research, 107, 1-12.

Ellis-Evans, J.C. 1996. Microbial diversity and function in Antarctic freshwater ecosystems. Biodiversity and Conservation, 11, 1395-1431.

Feinstein, L.M., Sul, W.J. \& Blackwood, C.B. 2009. Assessment of bias associated with incomplete extraction of microbial DNA from soil. Applied Environmental Microbiology, 75, 5428-5433.

FierER, N., JACKSON, J.A., VILGALYS, R. \& JACKSON, R.B. 2005. Assessment of soil microbial community structure by use of taxon-specific quantitative PCR assays. Applied Environmental Microbiology, 71, 4117-4120.

Friedmann, E.I., Kappen, L., Meyer, M.A. \& Nienow, J.A. 1993. Longterm productivity in the cryptoendolithic microbial community of the Ross Desert, Antarctica. Microbial Ecology, 25, 51-69.

Gilichinsky, D.A., Wilson, G.S., Friedmann, E.I. et al. 2007. Microbial populations in Antarctic permafrost: biodiversity, state, age, and implication for astrobiology. Astrobiology, 7, 275-311.

Hall, B.L. \& Denton, G.H. 2000. Radiocarbon chronology of Ross Sea drift, eastern Taylor Valley, Antarctica: evidence for a grounded ice sheet in the Ross Sea at the Last Glacial Maximum. Geografiska Annaler, 82A, 305-336.

Hall, B.L., Denton, G.H. \& Overturf, B. 2001. Glacial Lake Wright, a high-level Antarctic lake during the LGM and early Holocene. Antarctic Science, 13, 53-60.

Hall, B.L., Denton, G.H., Overturf, B. \& Hendy, C.H. 2002. Glacial Lake Victoria, a high-level Antarctic lake inferred from lacustrine deposits in Victoria Valley. Journal of Quaternary Science, 17, 697-706.

Hawes, I., Howard-Williams, C. \& Vincent, W.F. 1992. Dessication and recovery of Antarctic cyanobacterial mats. Polar Biology, 12, 587-594.

Johnson, S.S., Hebsgaard, M.B., Christensen, T.R., Mastepanov, M., Nielsen, R., Munch, K., Brand, T., Gilbert, M.T.P., Zuber, M.T., Bunce, M., Rønn, R., Gilichinsky, D., Froese, D. \& Willerslev, E. 2007. Ancient bacteria show evidence of DNA repair. Proceedings of the National Academy of Sciences of the United States of America, 104, 14 401-14 405.

Kennedy, M.J., Reader, S.L. \& Swierczynski, L.M. 1994. Preservation records of micro-organisms: evidence of the tenacity of life. Microbiology Reading English, 140, 2513-2529.

Legendre, P. \& Anderson, M.J. 1999. Distance-based redundancy analysis: testing multispecies responses in multifactorial ecological experiments. Ecological Monographs, 69, 1-24.

Lozupone, C., Hamady, M. \& Knight, R. 2006. UniFrac - an online tool for comparing microbial community diversity in a phylogenetic context. BMC Bioinformatics, 7, 371.

McKnight, D., Tate, C., Andrews, E., Niyogi, D., Cozzetto, K., Welch, K., Lyons, W. \& CAPONE, D. 2007. Reactivation of a cryptobiotic stream ecosystem in the McMurdo Dry Valleys, Antarctica: a long-term geomorphological experiment. Geomorphology, 89, 186-204.

Moodley, K. 2004. Microbial diversity of Antarctic dry valley mineral soil. MSc thesis, University of the Western Cape, 103 pp. [Unpublished.]
Moorhead, D.L., Doran, P.T., Fountain, A.G., Lyons, W.B., McKnight, D.M., Priscu, J.C., Virginia, R.A. \& Wall, D.H. 1999. Ecological legacies: impacts on ecosystems of the McMurdo Dry Valleys. BioScience, 49, 1009-1019.

Paerl, H.W., Pinckney, J.L. \& Steppe, T.F. 2000. Cyanobacteria and bacterial mat consortia: examining the functional unit of microbial survival and growth in extreme environments. Environmental Microbiology, 2, 11-26.

Ritchie, P.A., Millar, C.D., GibB, G.C., Baroni, C. \& Lambert, D.M. 2004. Ancient DNA enables timing of the Pleistocene origin and Holocene expansion of two Adélie penguin lineages in Antarctica. Molecular Biology and Evolution, 21, 240-248.

Rivkina, E.M., Friedmann, E.I., McKay, C.P. \& Gilichinsky, D.A. 2000. Metabolic activity of permafrost bacteria below the freezing Point. Applied and Environmental Microbiology, 66, 3230-3233.

Rollo, F., Luciani, S., Marota, I., Olivieri, C. \& Ermini, L. 2007. Persistence and decay of the intestinal microbiota's DNA in glacier mummies from the Alps. Journal of Archaeological Science, 34, 1294-1305.

ŠABACKÁ, M. \& Elster, J. 2006. Response of cyanobacteria and algae from Antarctic wetland habitats to freezing and desiccation stress. Polar Biology, 30, 31-37.

Schloss, P.D. \& Handelsman, J. 2005. Introducing DOTUR, a computer program for defining operational taxonomic units and estimating species-richness. Applied and Environmental Microbiology, 71, $1501-1506$.

Shirkey, B., McMaster, N.J., Smith, S.C., Wright, D.J., Rodriguez, H., Jaruga, P., Birincioglu, M., Helm, R.F. \& Potts, M. 2003. Genomic DNA of Nostoc commune (Cyanobacteria) becomes covalently modified during long-term (decades) desiccation but is protected from oxidative damage and degradation. Nucleic Acids Research, 31, 2995-3005.

Smith, J.J., Tow, L.A., Stafford, W., Cary, C. \& Cowan, D.A. 2006. Bacterial diversity in three different Antarctic cold desert mineral soils. Microbial Ecology, 51, 413-421.

Stackebrandt, E. \& Goebel, B.M. 1994. Taxonomic note: a place for DNA-DNA reassociation and 16S rRNA sequence analysis in the present species definition in bacteriology. International Journal of Systematic Bacteriology, 44, 846-849.

Suzina, N.E., Mulyukin, A.L., Kozlova, A.N., Shorokhova, A.P., Dmitriev, V.V., Barinova, E.S., Mokhova, O.N., El'-Registan, G.I. \& DuDA, V.I. 2004. Ultrastructure of resting cells of some non-sporeforming bacteria. Microbiology, 73, 435-447.

Van Trappen, S., Mergaert, J., van Eygen, S., Dawyndt, P., Cnockaert, M.C. \& SwINGS, J. 2002. Diversity of 746 heterotrophic bacteria isolated from microbial mats from ten Antarctic lakes. Systematic and Applied Microbiology, 25, 603-610.

VINCENT, W.F. 2000. Evolutionary origins of Antarctic microbiota: invasion, selection and endemism. Antarctic Science, 12, 374-385.

Wang, Q., Garrity, G.M., Tiedje, J.M. \& Cole, J.R. 2007. Naive Bayesian classifier for rapid assignment of rRNA sequences into the new bacterial taxonomy. Applied and Environmental Microbiology, 73, 5261-5267.

Willerslev, E. \& Cooper, A. 2005. Ancient DNA. Proceedings of the Royal Society, B272, 3-16. 